\title{
KEWENANGAN PEMERINTAH PROVINSI BALI DALAM PEMUNGUTAN PAJAK PROGRESIF ${ }^{1}$
}

\author{
Oleh : \\ Ida Bagus Prayoga ${ }^{2}$
}

\begin{abstract}
Motor vehicle tax is one of important tax for local revenue in Province of Bali. The imposition of a progressive tax rate on motor vehicles in Province of Bali is the authorization from the Bali Provincial Regulation No. 1 of 2011. Motor vehicle tax is one type of provincial tax provided for in Law No 28 of 2009. The problem in this research is how the Bali Provincial Government Authority In Progressive Tax Withholding? and How Progressive Tax System Implementation In the province of Bali?. Those problems are studied by using a method of normative legal research with statute approach, and conceptual approach. According to Law No. 28 of 2009, is clearly defined in Article 2 (1) that one type of tax is the provincial motor vehicle tax; based on that article, the Provincial Government of Bali has authority in the motor vehicle tax collection. the Bali Provincial Regulation No 1 of 2011 on local taxes. Progressive tax applies after second vehicle ownership, for 4-wheel vehicles or more
\end{abstract}

Keywords : Authorization, Motor Vehicle Tax, Progressive Tax Rate

\begin{abstract}
Abstrak
Pajak kendaraan bermotor memiliki peran penting dalam peningkatan pendapatan daerah di Provinsi Bali. Pengenaan tarif pajak progresif kendaraan bermotor di Provinsi Bali adalah wewenang yang diperoleh dari Peraturan Daerah Provinsi Bali No. 1 tahun 2011. Pajak kendaraan bermotor sendiri merupakan salah satu jenis Pajak Provinsi yang diatur dalam UU No 28 Tahun 2009. Masalah dalam penelitian ini adalah Bagaimanakah Kewenangan Pemerintah Provinsi Bali Dalam Pemungutan Pajak Progresif ? dan Bagaimanakah Sistem Penerapan Pajak Progresif Di Provinsi Bali ? Jenis penelitian ini menggunakan metode penelitian normatif. Jenis pendekatan yang digunakan adalah pendekatan perundang-undangan, dan pendekatan konseptual Menurut Undang-Undang No 28 Tahun 2009, secara jelas dirumuskan di dalam Pasal 2 ayat (1) bahwa salah satu jenis Pajak Provinsi adalah Pajak Kendaraan Bermotor; Berdasarkan Pasal tersebut maka Pemerintah Daerah Provinsi Bali memiliki kewenangan dalam pemungutan pajak kendaraan bermotor. dalam Peraturan Daerah Provinsi Bali No 1 Tahun 2011 tentang Pajak Daerah. Pajak progresif ini berlaku bagi kepemilikan kedua dan seterusnya untuk kendaraan roda 4 (empat) atau lebih.
\end{abstract}

Kata Kunci : Kewenangan, Pajak Kendaraan Bermotor, Tarif Pajak Progresif

Artikel ini merupakan karya ilmiah mahasiswa pada Program Studi Magister (S2) 1lmu Hukum Program Pascasarjana Universitas Udayana Serta mengucapkan terima kasih kepada Prof Dr I Wayan Parsa, S.H, M.Hum, dan Dr. I Gede Yusa, S.H, M.H Selaku Pembimbing Tesis

2 Mahasiswa Program Studi Magister (S2) llmu Hukum Program Pascasarjana Universitas Udayana, Denpasar Bali. Email : bagus_yoga88@yahoo.com 


\section{PENDAHULUAN}

Penyerahan urusan pemerintah pusat kepada pemerintah daerah berkaitan dengan asas desentralisasi, menurut Joeniarto dalam Ni'matul Huda, Desentralisasi adalah memberikan wewenang dari pemerintah negara kepada pemerintah lokal untuk mengatur dan mengurus urusan tertentu sebagai urusan rumah tangganya sendiri. ${ }^{3}$

Undang-Undang Nomor 23 Tahun 2014 Tentang Pemerintahan Daerah (selanjutnya disingkat UU No 23 Tahun 2014) dalam Pasal 1 angka 8 menyebutkan "Desentralisasi adalah penyerahan Urusan Pemerintahan oleh Pemerintah Pusat kepada daerah otonom berdasarkan Asas Otonomi”. Dalam Pasal 1 angka 6 menyebutkan "Otonomi Daerah adalah hak, wewenang, dan kewajiban daerah otonom untuk mengatur dan mengurus sendiri Urusan Pemerintahan dan kepentingan masyarakat setempat dalam sistem Negara Kesatuan Republik Indonesia."

Otonomi daerah merupakan konseppembangunanekonomiberbasis desentralisasi di Indonesia, dimana adanya pemberian kewenangan secara luas bagi Pemerintah Daerah (Pemda) untuk melakukan pembaharuan terhadap sistem pengelolaan daerah dan anggaran daerah. Penerapan otonomi daerah diharapkan agar setiap daerah mampu menggali dan

Ni'matul Huda, 2005, Hukum Tata Negara Indonesia, PT RajaGrafindo Persada, Jakarta, hlm. 307. mengembangkan potensi daerah yang dimiliki sehingga mampu memperoleh pendapatan dan membiayai daerahnya yang akan menentukan keberhasilan penerapan kebijakan otonomi daerah tersebut.

Secara etimologis otonomi berasal dari bahasa Latin, yaitu "autos" yang berarti "sendiri" dan "nomos" yang berarti aturan, Amran Muslimin mengatakan bahwa otonomi itu salah satu dari asas-asas pemerintahan negara, dimanapemerintahsuatunegara melaksanakansuatukepentinganumum untuk mencapai tujuan. Di samping itu, Ateng Syarifudin mengemukakan bahwa otonomi mempunyai makna kebebasan atas kemandirian, tetapi bukan kemerdekaan. Kemerdekaan terbatas atau kemandirian adalah wujud pemberian kesempatan yang harus dipertanggungjawabkan. ${ }^{4}$

Prinsip Desentralisasi tersebut juga mengatur mengenai hubungan pusat dan daerah dalam hal perpajakan, Menurut Adriani dalam Bonari ${ }^{5}$ Pajak adalah iuran pada negara yang dapat dipaksakan yang terutang oleh yang wajib membayarnya menurut peraturan-peraturan dengan tidak dapat prestasi kembali, yang langsung dapat ditunjuk, yang gunanya adalah untuk membiayai pengeluaran-pengeluaran umum berhubungan dengan tugas pemerintah.

4 Adrian Sutedi, 2008, Hukum Pajak dan Retribusi Daerah, Ghalia Indonesia, Jakarta, hlm. 1.

Bonari, 2004, Pengantar Hukum Pajak, RajaGrafindo Persada, Jakarta, hlm. 23. 
Pajak berperan penting dalam pembangunan karena dua fungsi yang melekatpadanya,yaknifungsi budgeter dan fungsi regulerend. Fungsi budgeter pajak adalah mengisi kas negara dalam rangka melancarkan roda pemerintahan dengan cara mengumpulkan uang sebanyak-banyaknya sesuai dengan undang-undang yang berlaku yang pada waktunya akan digunakan untuk membiayai pengeluaran-pengeluaran negara, yaitu pengeluaran rutin dan pengeluaranpembangunan, danjikaada sisa (surplus) akan digunakan sebagai tabungan pemerintah. Sedangkan fungsi regulerend adalah fungsi yang dapat dimanfaatkan oleh pemerintah untuk menopang usaha pemerintah di bidang ekonomi, sosial, dan budaya sesuai yang telah ditetapkan dalam program pembangunan. ${ }^{6}$

Pemerintah Daerah atau "local government" adalah Bagian dari pemerintah suatu negara atau bangsa yang berdaulat yang dibentuk secara politis berdasarkan undang-undang yang memiliki lembaga atau badan yang menjalankan pemerintahan yang dipilih masyarakat daerah tersebut, dan dilengkapi dengan kewenangan untuk membuat peraturan, memungut pajak serta memberikan pelayanan kepada warga yang ada di dalam wilayah kekuasaannya.

Sebagaimana disebutkan dalam UU No 23 Tahun 2014 Pasal 279 ayat (1) dan ayat (2) huruf a :

Ibid, hlm 133
"Pemerintah Pusat memiliki hubungan keuangan dengan Daerah untuk membiayai penyelenggaraan Urusan Pemerintahan yang diserahkan dan/atau ditugaskan kepada Daerah, Hubungan keuangan dalam penyelenggaraan Urusan Pemerintahan yang diserahkan kepada Daerah meliputi: pemberian sumber penerimaan Daerah berupa pajak daerah dan retribusi daerah"

Dalam Undang-Undang Nomor 28 Tahun 2009 tentang Pajak dan Retribusi Daerah (selanjutnya disingkat UU No 28 Tahun 2009) Pasal 1 angka 10 menyebutkan bahwa:

"Pajak Daerah, yang selanjutnya disebut Pajak, adalah kontribusi wajib kepada Daerah yang terutang oleh orang pribadi atau badan yang bersifat memaksa berdasarkan Undang-Undang, dengan tidak mendapatkan imbalan secara langsung dan digunakan untuk keperluan Daerah bagi sebesar-besarnya kemakmuran rakyat."

Pajak dan retribusi daerah merupakan salah satu pendapatan daerah yang tergolong kedalam PAD (pendapatan asli daerah). Dalam pajak dan retribusi daerah, Provinsi dan Kabupaten/Kota dibagi dalam hal kewenangannya menetapkan pajak. Pajak daerah Provinsi sebagai kewenangan daerah Provinsi untuk ditetapkan dalam bentuk peraturan daerah adalah sebagai berikut :

a. Pajak Kendaraan bermotor ;

b. Bea balik nama kendaraan bermotor; 
c. ajak bahan bakar kendaraan bermotor

d. Pajak air permukaan; dan

e. Pajak rokok. ${ }^{7}$

Dalam Pasal 6 UU No 28 tahun 2009, kendaraan bermotor dikenakan sistem pajak progresif Kepemilikan Kendaraan Bermotor didasarkan atas nama dan/ atau alamat yang sama. Sistem progresif, yaitu bila rasio jumlah pajak yang dibayarkan terhadap penghasilan wajib pajak adalah meningkat sejalan dengan naiknya penghasilan wajib pajak, jika dikaitkan dengan kepemilikan kendaraan bermotor maka pengenaan pajak progresif dikenakan kepada kepemilikan kendaraan bermotor mulai dari yang kedua dan seterusnya dari wajib pajak.

Di Provinsi Bali aturan mengenai Pajak Daerah telah tertuang dalam Peraturan Daerah Provinsi Bali Nomor 1 Tahun 2011 Tentang Pajak Daerah. (selanjutnya disingkat Perda No 1 Tahun 2011) Salah satu jenis pajak yang diatur dalam Perda No 1 Tahun 2011 adalah mengenai pajak Progresif Kendaraan Bermotor

Dalam Pasal 7 Perda No 1 Tahun 2011 disebutkan Tarif pajak progresif untuk berbagai jenis kendaraan plat hitam tersebut dengan ketentuan besaran pajak kendaraan pertama 1,5\% dari nilai jual sedang untuk kendaraan kedua $2 \%$, ketiga $2,5 \%$ keempat $3 \%$ dan lebih dari lima dikenakan 3,5\%.,

Djafar Saidi, 2011, Pembaruan Hukum Pajak, PT RajaGrafindo Persada, Jakarta, hlm. 34. dikecualikan terhadap kepemilikan kendaraan bermotor roda dua tidak dikenakan pajak progresif.

Berdasarkan latar belakang masalah diatas dapat dikemukakan dua permasalahan sebagai yaitu bagaimanakah kewenangan pemerintah daerah Provinsi Bali dalam pemungutan pajak progresif ? serta bagaimanakah sistem penerapan pajak progresif di Provinsi Bali ?

Penelitian dilakukan penulis melalui penelusuran bahan hukum, baik berupa peraturan perundangan maupun literatur hukum yang terkait dengan permasalahan yang akan dikaji dalam penelitian ini. Namun penulis menyadari bahwa terdapat beberapa tulisan ilmiah lain yang memiliki bahasan hampir sama dengan penelitian ini yaitu berkaitan dengan Kewenangan Pemerintah Provinsi Bali Dalam Pemungutan Pajak Progresif, antara lain :

1. Judul Penelitian : Dampak Pengenaan Tarif Pajak Progresif Kendaraan Bermotor Di Propinsi DKI Jakarta

Penulis : Eka Ermawati Ni Putu Eka Widiastuti, UPN "Veteran" Jakarta, Tahun 2014

Tujuan dari penelitiannya adalah untuk membuktikan secara emperis bahwa pengenaan tarif pajak progresif kendaraan bermotor berpengaruh signifikan terhadap perilaku penghindaran pajak di DKI Jakarta. 
2. Judul Penelitian : Analisis Pengenaan Tarif Pajak Progresif Pada Pajak Kendaraan Bermotor Berdasarkan "The Four Maxims"

Penulis : Fajariani, Universitas Negeri Surabaya, Tahun 2013

Tujuan Penelitiannya adalah untuk lebih mengenal tentang pajak kendaraan bermotor dan mengetahui bagaimana pengenaan tarif pajak progresif pada kendaraan bermotor di Jawa Timur. Kemudian dilakukan analisis apakah pengenaan tarif pajak progresif tersebut sesuai dengan asas-asas pemungutan pajak.

3. Judul Penelitian : Analisis Perbandingan Sebelum Dan Sesudah Pengenaan Tarif Pajak Progresif Pada Kendaraan Bermotor Berdasarkan "TheFour Maxims" Di Kota Manado

Penulis : Eugenia Rosalie, Jantje Tinangon, Rudy Pusung, Universitas Sam Ratulangi, Manado, Tahun 2013

Tujuan yang ingin dicapai dalam penelitian ini adalah :. Untuk mengetahui penerapan tarif pajak progresif pada kendaraan bermotor di Kota Manado, Untuk mengetahui penerapan tarif pajak progresif pada kendaraan bermotor berdasarkan asas-asas pemungutan pajak serta Untuk mengetahui efektifitas tujuan pengenaan pajak progresif terhadap fungsi dari pajak yaitu sebagai Budgetair atau Regulerend.

Perbedaan penelitian ini dengan tulisan-tulisan yang dipaparkan di atas terletak pada fokus kajiannya, dimana kajian dalam penelitian ini berkaitan dengan dasar kewenangan pemerintah daerah Provinsi Bali dalam pemungutan pajak progresif serta bagaimana sistem penerapan pajak progresif di Provinsi Bali

Adapun tujuan penulisan penelitian ini adalah untuk mendeskripsikan tentang Kewenangan Pemerintah Provinsi Bali dalam Pemungutan Pajak progresif berdasarkan UU No 23 tahun 2014 tentang Pemerintahan Daerah, UU No 28 Tahun 2009 Tentang Pajak Daerah dan retribusi Daerah, dan berdasarkan Perda Provinsi Bali No 1 Tahun 2011 tentang Pajak daerah dan juga untuk mendeskripsikan bagaimana sistem penerapan pajak progresif di Provinsi Bali

\section{METODE PENULISAN}

Jenis penelitian yang digunakan dalam penulisan ini adalah jenis penelitian normatif yaitu penelitian dengan melihat pada ketentuan hukum dalam peraturan perundang-undangan yang berlaku, yang kemudian dikaitkan dengan permasalahan yang dibahas. ${ }^{8}$ Jenis pendekatan yang digunakan adalah pendekatan

Peter Mahmud Marzuki, 2005, Penelitian Hukum, Fajar Interpratama Offset, Jakarta, hlm. 93. 
perundang-undangan, dan pendekatan konseptual.

III. HASIL DAN PEMBAHASAN 3.1 Kewenangan Pemerintah Provinsi Bali Dalam Pemungutan Pajak Progresif Setiap penyelenggaraan kenegaraan dan pemerintah harus memiliki legitimasi, yaitu kewenangan yang diberikan oleh peraturan perundang-undangan. Dengan demikian substansi asas legalitas adalah wewenang, yakni kemampuan untuk melakukan tindakan-tindakan hukum tertentu. ${ }^{9}$

Menurut Robert Birstedt, ${ }^{10}$ bahwa wewenang adalah kekuasaan yang dilembagakan. Kewenangan merupakan wujud nyata dari kekuasaan. Sementara itu, menurut Miriam Budiardjo, kekuasaan adalah kemampuan untuk mempengaruhi tingkah laku pelaku lain sedemikian rupa, sehingga tingkah laku terakhir menjadi sesuai dengan keinginan pelaku yang mempunyai kekuasaan. ${ }^{11}$

Menurut Bagir Manan, ${ }^{12}$ wewenang dalam bahasa hukum tidak sama dengan kekuasaan (macht). Kekuasaan hanya menggambarkan hak untukberbuat atautidak berbuat. Dalam hukum, wewenang sekaligus berartihak

9 Ridwan HR, 2006, Hukum Administrasi Negara, PT RajaGrafindo Persada, Jakarta, hlm. 100

10 Firmansyah Arifin, 2005, dkk, Lembaga Negara Dan Sengketa Kewenangan Antar Lembaga Negara, Konsorsium Reformasi Hukum Nasional, Jakarta, hlm. 16

$11 \quad$ Ibid

12 Ridwan HR, Op.Cit, hlm. 102 dan kewajiban. Dalam negara hukum, wewenang pemerintahan itu berasal dari peraturan perundang-undangan yang berlaku, organ pemerintahan tidak dapat menganggap bahwa organ tersebut memiliki sendiri wewenang pemerintahan. Kewenangan hanya diberikan oleh peraturan perundangundangan. ${ }^{13}$

Seiring dengan pilar utama negara hukum, yaitu asas legalitas, berdasarkan prinsip ini tersirat bahwa wewenang pemerintahan berasal dari peraturanperundang-undangan, artinya sumber wewenang bagi pemerintah adalah peraturan perundang-undangan. Secara teoritis, kewenangan yang bersumber dari peraturan perundangundangan tersebut diperoleh melalui tiga cara yaitu atribusi, delegasi, dan mandat.

Mengenai atribusi, delegasi, dan mandat ini, H.D. Van Wijk/Willem Konijnenbelt mendefinisikan sebagai berikut : ${ }^{14}$

a. Atribusi adalah pemberian wewenang pemerintahan oleh peraturan perundang-undangan kepada organ pemerintahan

b. Delegasi adalah pelimpahan wewenang pemerintahan dari satu organ pemerintahan kepada organ pemerintahan lainnya

c. Mandat terjadi ketika organ pemerintahan mengizinkan kewenangannya dijalankan oleh organ lain atas namanya.

Pemerintah daerah secara

Ibid, hlm. 104 
konstitusional, dimana wilayah Negara Kesatuan Republik Indonesia dibagi atas daerah-daerah provinsi dan daerah provinsi dibagi atas kabupaten dan kota, yang tiap-tiap provinsi, kabupaten dan kota mempunyai pemerintahan daerah serta bentuk susunan pemerintahannya diatur dengan undang-undang. Pemerintahan Negara membagi-bagi pemerintahan menjadi pemerintahan daerah, yang bertujuan mempercepat kesejahteraan bagi masyarakat dalam ikatan Negara Kesatuan Republik Indonesia

Keberadaan pemerintah daerah berdasarkan asas desentralisasi juga dapat diartikan sebagai pengakuan atau penyerahan wewenang oleh badan-badan publik yang lebih tinggi kepada badan-badan publik yang lebih rendah kedudukannya untuk secara mandiri dan berdasarkan kepentingan sendiri mengambil keputusan di bidang pengaturan dan di bidang pemerintahan. ${ }^{15}$

Negara Republik Indonesia sebagai Negara kesatuan menganut asas desentralisasi dalam penyelenggaraan pemerintahan, dengan memberikan kesempatan dan keleluasaan kepada daerah untuk menyelenggarakan otonomi dalam pembuatan peraturan perundangundangan, maupun pemerintah dari pemerintah pusat kepada pemerintah daerah untuk selanjutnya menjadi

15 Jimly Asshiddiqie, 2006, Pengantar Ilmu Hukum Tata Negara, Sekretariat Jenderal dan Kepaniteraan Mahkamah Konstitusi, Jakarta hlm. 27. urusan rumah tangganya sendiri. Desentralisasi pemerintahan yang pelaksanaannya diwujudkan dengan pemberian otonomi daerah kepada daerah-daerah didalam meningkatkan daerah-daerah mencapai daya guna dan hasil guna penyelenggaraan pemerintahan dalam rangka pelayanan terhadap masyarakat dan pelaksanaan pembangunan. Dengan demikian daerah perlu diberikan wewenang untuk melaksanakan berbagai urusan pemerintahan sebagai urusan rumah tangganya, serta sekaligus memiliki pendapatan daerah. ${ }^{16}$

Berdasarkan Pasal 285 UU No 23 Tahun 2014, dirumuskan bahwa sumber pendapatan daerah berasal dari 3 sumber yaitu :

1. pendapatan asli Daerah meliputi:

a. pajak daerah;

b. retribusi daerah;

c. hasil pengelolaan kekayaan Daerah yang dipisahkan; dan

d. lain-lain pendapatan asli Daerah yang sah;

2. pendapatan transfer; dan

3. lain-lain pendapatan Daerah yang sah.

Dari sekian sumber-sumber PendapatanAslidaerahdiatas, diketahui bahwa Pajak Daerah merupakan salah satu sumber pendapatan daerah yang paling penting, oleh karena itu di setiap tahunnya pajak daerah dapat

16 Ni'matul Huda, Op.Cit, hlm. 308 
memberikan sumbangan yang cukup besar bagi penerimaan daerah, selain itu melalui pajak daerah diharapkan menjadi salah satu sumber pembiayaan penyelenggaraan pemerintahan dan pembangunan untuk meningkatkan dan memeratakan kesejahteraan masyarakat. sehingga, dengandemikian daerah mampu melaksanakan otonomi yaitu mampu mengatur dan mengurus rumah tangganya sendiri.

Berdasarkan Pasal 1 Angka (10) UU No 28 Tahun 2009 disebutkan bahwa :

"Pajak Daerah, yang selanjutnya disebut Pajak, adalah kontribusi wajib kepada Daerah yang terhutang oleh orang pribadi atau badan yang bersifat memaksa berdasarkan Undang-Undang, dengan tidak mendapatkan imbalan secara langsung dan digunakan untuk keperluan Daerah bagi sebesar-besarnya kemakmuran rakyat."

Faktor kemampuan mengelola keuangandaerahmerupakanfaktoryang cukup menentukan bagi keberhasilan pelaksanaan otonomi daerah. dengan kata lain salah ciri daerah otonom terletak pada kemampuan daerahnya di bidang keuangan termasuk di dalamnya kemampuan daerah dalam pemungutan sumber-sumber keuangan daerah dengan baik dan menggunakan secara tepat dan benar. Dimana daerah harus mempunyai sumber-sumber keuangan yang memadai untuk membiayai penyelenggaraan otonominya
Dasar hukum pelaksanaan otonomi daerah di Indonesia didasarkan atas pasal 18 ayat (1) UUD 1945 sebagai berikut. "Negara Kesatuan Republik Indonesia dibagi atas daerahdaerah provinsi dan daerah provinsi itu dibagi atas kabupaten dan kota, yang tiap-tiap provinsi, kabupaten, dan kota itu mempunyai pemerintahan daerah, yang diatur dengan undang-undang. dalam ayat (1) ditegaskan bahwa Pemerintahan daerah provinsi, daerah kabupaten, dan kota mengatur dan mengurus sendiri urusan pemerintahan menurut asas otonomi dan tugas pembantuan. Kemudian dalam ayat (5) dinyatakan bahwa Pemerintahan daerah menjalankan otonomi seluas luasnya, kecuali urusan pemerintahan yang oleh undang - undang ditentukan sebagai urusan Pemerintah Pusat.

Dalam penjelasan pasal tersebut dirumuskan bahwa wilayah negara Indonesia akan dibagi menjadi daerah Provinsi, kemudian provinsi akan dibagi akan dibagi pula menjadi daerah kabupaten dan kota. Daerah-daerah tersebut bersifat otonom atau bersifat daerah administrasi belaka, dimana semuanya menurut aturan yang akan ditetapkan dengan undang-undang.

Dalam Pasal 279 UU No 23 Tahun 2014 dirumuskan bahwa :

(1) Pemerintah Pusat memiliki hubungan keuangan dengan Daerah untuk membiayai penyelenggaraan Urusan Pemerintahan yang diserahkan dan/atau ditugaskan kepada Daerah. 
(2) Hubungan

keuangan

dalam penyelenggaraan

Urusan Pemerintahan yang

diserahkan kepada Daerah

sebagaimana dimaksud pada ayat (1) meliputi:

a. pemberian

sumber

penerimaan Daerah berupa

pajak daerah dan retribusi daerah;

b. pemberian dana bersumber dari perimbangan keuangan antara Pemerintah Pusat dan Daerah;

c. pemberian dana penyelenggaraan otonomi khusus untuk Pemerintahan Daerah tertentu yang ditetapkan dalam undangundang; dan

d. pemberian pinjaman dan/ atau hibah, dana darurat, dan insentif (fiskal).

Menurut Undang-Undang No 28 Tahun 2009, secara jelas dirumuskan di dalam Pasal 2 ayat (1) bahwa jenis Pajak Provinsi terdiri dari :

a. ajak Kendaraan Bermotor;

b. Bea Balik Nama Kendaraan Bermotor;

c. Pajak Bahan Bakar Kendaraan Bermotor;

d. Pajak Air Permukaan; dan

e. Pajak Rokok.

Berdasarkan Pasal tersebut maka Pemerintah Daerah Provinsi Bali memiliki kewenangan dalam pemungutan pajakkendaraanbermotor. Mengenai ketentuan tersebut lebih lanjut diatur dalam Peraturan Daerah
Provinsi Bali No 1 Tahun 2011 tentang Pajak Daerah.

Dimana dalam Pasal 7 Perda No 1 tahun 2011 disebutkan bahwa pajak kendaraan bermotor dikenakan Tarif pajak progresif dengan ketentuan besaran pajak kendaraan pertama 1,5\% dari nilai jual sedang untuk kendaraan kedua $2 \%$, ketiga $2,5 \%$ keempat $3 \%$ dan lebih dari lima dikenakan 3,5\%., dikecualikan terhadap kepemilikan kendaraan bermotor roda dua tidak dikenakan pajak progresif.

Sedangkan untuk angkutan umum Kendaraan bermotor TNI/ POLRI, Pemerintah Pusat dan Pemerintah Daerah ambulans, mobil jenazah pemadam kebakaran sosial keagamaan, lembaga sosial dan keagamaan alat-alat berat dan alat-alat besar ditetapkan sebagai berikut :

a. angkutan umum dikenakan tarif PKB sebesar $1 \%$,

b. Kendaraan bermotor TNI/ POLRI, Pemerintah Pusat dan Pemerintah Daerah, ambulans, mobil jenazah, pemadam kebakaran, kendaraan sosial keagamaan, lembaga sosial sebesar 0,50\%;

c. alat-alat berat dan alat-alat besar ditetapkan sebesar $0,20 \%$.

Tujuan dari dikenakannya tarif progresif adalah ${ }^{17}$ :

\footnotetext{
"Tinjauan Hukum Pajak Kendaraan bermotor dan Bea Balik Nama KEndaraan Bermotor Dalam Rangka Peningkatan Pendapatan Asli Daerah", hlm. 9 Tersedia dihttp://jdih.bpk. go.id/wp=conten/uploads/2013/05/TulisanHukumiPajak-Kendaraanikoreksi-Bu-Herny. pdf, diakses tanggal 10 Juli 2016
} 
1. Menciptakan rasa keadilan, penciptaanrasakeadilaninisesuai dengan salah satu konsideran Undang-Undang Nomor 28 Tahun 2009, yaitu kebijakan pajak daerah dan retribusi daerah dilaksanakan berdasarkan prinsip demokrasi, pemerataan dan keadilan, peran serta masyarakat, dan akuntabilitas dengan memperhatikan potensi daerah. Dengan penerapan pajak progresif, maka orang yang lebih mampu membeli/memiliki kendaraan akan membayar PKB lebih tinggi dari pada orang lain.

2. Meningkatkan Pendapatan Asli Daerah, penerapan pajak progresif dianggap lebih tepat dibandingkan dengan pengenaan pajak tinggi untuk mobil yang sudah tua atau berumur lebih dari lima tahun, karena akan menyulitkan masyarakat yang baru mampu membeli mobil bekas. Selain itu, pemberian pajak yang tinggi bagi mobil tua juga tidak mudah dilakukan.

3. Mewujudkan tertib administrasi, dengan pajak progresif, maka nama yang tercantum dalam STNK ataupun BPKB adalah benar-benar pemilik yang sah dan belum berpindah tangan. Dengan tertib administrasi tersebut, polisi bisa cepat menghubungi keluarga korban apabila ada kecelakaan lalu lintas karena ada kepastian identitas valid pemilik kendaraan bermotor.

4. Mengurangi tingkat kemacetan di daerah perkotaan, dengan diberlakukannya Pajak progresif yang ditujukan kepada pemilik kendaraan pribadi, diharapkan dapat mengurangi tingkat kemacetan di daerah perkotaan.

\subsection{Sistem Penerapan Pajak Progresif Di Provinsi Bali}

Pemberlakukan pajak progresif kendaraan bermotor di Provinsi Bali telah dimulai sejak Juni 2014. ${ }^{18}$ Dasar berlakunya pajak progresif ini terdapat dalam Pasal 6 UndangUndang Nomor 28 Tahun 2009 tentang Pajak Daerah dan Retribusi Daerah yang yang dituangkan lebih lanjut dalam Perda Provinsi Bali No 1 Tahun 2011 tentang Pajak Daerah. Tarif Pajak progresif ini berlaku bagi kendaraan bermotor kepemilikan kedua dan seterusnya berlaku bagi kendaraan roda 4 (empat) atau lebih. Dasar penetapan pajak progresif berdasarkan pada urutan tanggal pendaftaran kendaraan bermotor pada database objek kendaraan bermotor atau berdasarkan pernyataan Wajib Pajak. Dikecualikan terhadap kepemilikan kendaraan bermotor roda dua tidak dikenakan pajak secara progresif. Selanjutnya apabila terdapat perubahan kepemilikan, wajib pajak harus melaporkan untuk merubah urutan kepemilikan.

\footnotetext{
18 Income, 2014, Majalah Triwulan Dinas Pendapatan Provinsi Bali, Pajak Progresif Wujudkan Rasa Adil, hlm. 7.
} 
Pendataan kepemilikan kendaraan bermotor untuk penetapan pajak progresif kendaraan bermotor berdasarkan atas nama dan/atau alamat yang sama. Maksudnya adalah nama dan/atau alamat yang sama dalam suatu keluarga yang dibuktikan dengan Nomor Kartu Keluarga yang diterbitkan oleh instansi yang berwenang. ${ }^{19}$

Pelaksanaan penarikan pajak progresif dilakukan oleh Kantor Bersama Sistem Administrasi Manunggal Satu Atap (SAMSAT). Untuk wilayah Provinsi Bali, penarikan pajak progresif kendaraan bermotor dilaksanakan oleh Kantor Bersama SAMSAT Provinsi Bali.

Tahapan awal pendataan pajak progresif sesuai dengan ketentuan Standar Operasional Prosedur (SOP) Pengenaan Pajak Progresif Untuk Kendaraan Bermotor Pada Dinas Pendapatan Provinsi Bali Nomor : 973/4494/Pajak/Dispenda Bab VI angka 1 terdiri atas Wajib Pajak Melakukan Pengambilan dan Pengisian Formulir Pendataan Kendaraan Bermotor (FPKB), kemudian Wajib pajak mengambil Formulir Pendataan Kendaraan Bermotor (FPKB), Wajib pajak mengisi langsung Formulir (rangkap 2) atau anggota keluarga yang lain dalam 1(satu) Kartu Keluarga atau dapat dikuasakan Data isian, secara garis besar meliputi Data identitas berupa nama, alamat, no. KTP, no. KK, dan nomor Handphone Data kendaraan berupa nomor polisi, jenis, merek, tipe, tahun, warna, tanggal kwitansi/pembelian, status kendaraan (dimiliki, dikuasai, telah terjual, tidak berfungsi/rusak, dan hilang)

Dasar pemungutan pajak progresif ini tercantum dalam Pasal 7 Peraturan Daerah Provinsi Bali Nomor 1 Tahun 2011 tentang Pajak Daerah. Adapun besarnya tarif pajak progresif tersebut adalah sebagai berikut:

1) Kepemilikan kedua sebesar $2 \%$ (dua persen)

2) Kepemilikan ketiga sebesar 2,5\% (dua koma lima persen)

3) Kepemilikan keempat sebesar 3\% (tiga persen)

4) Kepemilikan kelima dan seterusnya sebesar $3,5 \%$ (tiga koma lima persen).

Dalam ketentuan Standar Operasional Prosedur (SOP) Pengenaan Pajak Progresif Untuk Kendaraan Bermotor Pada Dinas Pendapatan Provinsi Bali Nomor : 973/4494/Pajak/Dispenda Bab III angka 5 disebutkan bahwa Kendaraan Bermotor yang dikenakan pajak progresif yaitu kendaraan bermotor Plat Hitam dengan fungsi Pribadi Roda 4 (empat) atau lebih, seperti :

- $\quad$ Sedan dan sejenisnya

- Jeep dan sejenisnya

- $\quad$ Station Wagon dan sejenisnya

- Mikrobus, dan

- $\quad$ Pickup Double cabin

Karenapajak progresifkendaraan bermotor dikenakan berdasarkan nama dan/atau alamat yang sama dalam satu 
kartu keluarga, maka wajib pajak yang memiliki kendaraan bermotor lebih dari satu unit wajib melakukan proses balik nama terhadap kendaraan bermotor yang dimilikinya, agar tidak terdaftar di database bahwa kendaraankendaraan tersebut ternyata dimiliki oleh satu individu saja.

Berdasarkan hal tersebut, Wajib Pajak yang telah menjual kendaraan bermotor harus menyampaikan laporan kepada pihak Dinas Pendapatan Provinsi Bali /SAMSAT. Tujuannya adalah menyatakan bahwa kendaraan yang dimilikinya telah dijual. Berdasarkan laporan dari Wajib Pajak tersebut petugas Dinas Pendapatan Provinsi Bali/SAMSAT akan melakukan pemblokiran terhadap nomor polisi kendaraan yang telah dijual. Sebab jika tidak dilakukan pemblokiran, maka kendaraan yang telah dijual tersebut masih atas nama pemilik pertama atau penjual, sehingga pemilik pertama atau penjual akan terkena tarif progresif Kendaraan bermotor untuk kendaraan yang sebenarnya sudah bukan miliknya lagi.

Prosesblokir atasnamakendaraan yang telah dijual dimaksudkan untuk memutakhirkan data kendaraan yang terdaftar di SAMSAT, dengan tujuan agar pihak SAMSAT memiliki data yang lebih akurat tentang jumlah kendaraan maupun status kendaraan yang menjadi obyek pajak, sebagai dasar terhadap pendataan pemilik kendaraan yang terkena atau tidak terkena tarif progresif kendaraan bermotor.

Pemblokiran kendaraan bermotor hanya dapat dilakukan bagi kendaraan yang telah didaftarkan statusnya dengan "Dikuasai tetapi Tidak Dimiliki". Dalam artian kendaraan dikuasai, tetapi masih atas nama pihak lain tidak dalam satu nomor kartu keluarga (belum balik nama). Harus memasukkan tanggal kwitansi apabila status ini dipilih. Berdasarkan Standar Operasional Prosedur (SOP) Pengenaan Pajak Progresif Untuk Kendaraan Bermotor Pada Dinas Pendapatan Provinsi Bali Nomor : 973/4494/Pajak/Dispenda Bab VII, tahapannya adalah sebagai berikut :

1) Wajib Pajak Melakukan Pengambilan dan Pengisian Surat Permohonan Blokir

a. Wajib pajak mengambil Surat Permohonan pemblokiran kendaraan

b. Data isian, secara garis besar meliputi :

- Dataidentitas:nama,tempat, tanggal lahir, alamat, dan no. KTP

- Data transaksi : jenis transaksi, s/d tanggal buka blokir, dan alasan

- Data kendaraan : nomor polisi, warna plat, atas nama, alamat, jenis kendaraan, merek, tipe dan tahun.

c. Surat Permohonan pemblokiran kendaraan di tandatangani oleh pemohon. 
Kemudian Wajib Pajak Menyerahkan Surat Permohonan pemblokiran kendaraan dan dokumen lainnya. Wajib pajak menyerahkan Formulir Pendataan Kendaraan Bermotor, KTP (fotocopy) dan dokumen lainnya seperti Surat Keterangan BPKB sebagai Jaminan Bank bila dijaminkan, Surat Keterangan Kepolisian bila BPKB Hilang, dll kepada petugas di Loket Pajak Progresif.

2) Petugas Pendataan Pajak Progresifmelakukan pengecekan dokumen

a. Petugas Pendataan Progresif melakukan pengecekan dokumen meliputi : Surat Permohonan Pembukaan Blokir Kendaraan Bermotor yang telah diisi dan ditandatangani, KTP (fotocopy) dan dokumen lainnya seperti Surat Keterangan BPKB sebagai Jaminan Bank/lembaga penjamin lainnya, Surat Keterangan Kepolisian bila BPKB Hilang, dll.

b. Permohonan pemblokiran kendaraan disetujui apabila :

- Ada kendaraan diharuskan transaksi balik nama karena kendaraan tersebut diblokir oleh pemilik, namun karena BPKB menjadi jaminan Bank maka transaksi balik nama tidak dapat dilakukan. Hal ini dibuktikan dengan Surat Keterangan dari Bank/ lembaga penjamin lainnya bahwa BPKB sedang menjadi jaminan.

- Ada kendaraan diharuskan transaksi balik nama karena kendaraan tersebut diblokir oleh pemilik, namun karena BPKB hilang maka transaksi balik nama tidak dapat dilakukan. Hal ini dibuktikan dengan Surat Keterangan kepolisian bila BPKB hilang.

3) Petugas Pendataan Pajak Progresif melakukan Pencarian Data Kendaraan sesuai Surat Permohonan pemblokiran kendaraan

a. Petugas melakukan pencarian data kendaraan berdasarkan data isian di Surat Permohonan pemblokiran kendaraan dengan jenis pencarian melalui No Polisi.

b. Hasil pencarian keseluruhan dapat diketahui langsung oleh wajib pajak melalui dual monitor.

4) Petugas Pendataan Pajak Progresif melakukan Input Data Buka Blokir Sesuai Surat Permohonan Blokir.

Dari hasil pencarian data kendaraan, kemudian di input data tanggal batas transaksi ke dalam sistem. Tanggal batas transaksi maksimal diberikan sesuai kebutuhan.

5) Apabila proses input telah dilakukan, Petugas Pendataan Pajak Progresif menandatangani Surat Permohonan Blokir. 
Surat Permohonan Blokir yang sudah disetujui kemudian ditandatangani oleh Kasi Pelayanan PKB dan BBNKB atau petugas yang berwenang. Berdasarkan proses tersebut SAMSAT/DispendaProvinsiBali akan melakukan pemutakhiran data pemilik kendaraan yang telah dijual. Dengan sistem itu, pemilik lama/penjual tidak akan terkena tarif progresif kendaraan bermotor. Pajak kendaraan yang dijual itu akan dibebankan kepada pemilik baru kendaraan bermotor.

Selain itu Penerapan pajak progresif terhadap kendaraan bermotor ini mampu meningkatkan Pendapatan Asli Daerah (PAD) Provinsi Bali. Karena dengan meningkatnya jumlah pajak yang harus dibayarkan oleh wajib pajak, tentu saja berpengaruh terhadap PAD Provinsi Bali.

\section{KESIMPULAN}

1. Dasar hukum pelaksanaan otonomi daerah di Indonesia didasarkan atas pasal 18 UUD 1945, dimana Pemerintah Pusat memiliki hubungan keuangan dengan Daerah untuk membiayai penyelenggaraan Urusan Pemerintahan yang diserahkan dan/atau ditugaskan kepada Daerah. Dari sekian sumber-sumber Pendapatan Asli daerah, diketahui bahwa Pajak Daerah merupakan salah satu sumber pendapatan daerah yang paling penting, oleh karena itu di setiap tahunnya pajak daerah dapat memberikan sumbangan yang cukup besar bagi penerimaan daerah Menurut Undang-Undang No 28 Tahun 2009, secara jelas dirumuskan di dalam Pasal 2 ayat (1) bahwa jenis Pajak Provinsi terdiri dari : Pajak Kendaraan Bermotor; Bea Balik Nama Kendaraan Bermotor; Pajak Bahan Bakar Kendaraan Bermotor; Pajak Air Permukaan; dan Pajak Rokok. Dimana dalam Pasal 7 Perda No 1 tahun 2011 disebutkan bahwa pajak kendaraan bermotor dikenakan Tarif pajak progresif dengan ketentuan besaran pajak kendaraan pertama 1,5\% dari nilai jual sedang untuk kendaraan kedua 2\%, ketiga 2,5\% keempat $3 \%$ dan lebih dari lima dikenakan 3,5\%., dikecualikan terhadap kepemilikan kendaraan bermotor roda dua tidak dikenakan pajak progresif.

2. Pajak progresif untuk kendaraan bermotor mulai diberlakukan di Provinsi Bali sejak Juni 2014. Dasar Berlakunya pajak progresif ini adalah pasal 6 Undang-Undang Nomor 28 Tahun 2009 tentang Pajak Daerah dan Retribusi Daerah yang pelaksanaannya ditetapkan dalam Peraturan Daerah Provinsi Bali No 1 Tahun 2011 tentang Pajak Daerah. Pendataan kepemilikan kendaraan bermotor 
untuk penetapan pajak progresif kendaraan bermotor berdasarkan atas nama dan/atau alamat yang sama. Maksudnya adalah nama dan/atau alamat yang sama dalam suatu keluarga yang dibuktikan dengan Nomor Kartu Keluarga yang diterbitkan oleh instansi yang berwenang. Proses blokir atas nama kendaraan yang telah dijual dimaksudkan untuk memutakhirkan data kendaraan yang terdaftar di SAMSAT, dengan tujuan agar pihak SAMSAT memiliki data yang lebih akurat tentang jumlah kendaraan maupun status kendaraan yang menjadi obyek pajak, sebagai dasar terhadap pendataan pemilik kendaraan yang terkena atau tidak terkena tarif progresif kendaraan bermotor

\section{DAFTAR PUSTAKA}

\section{Buku}

Arifin, Firmansyah, 2005, dkk, Lembaga Negara Dan Sengketa Kewenangan Antar Lembaga Negara, Konsorsium Reformasi Hukum Nasional, Jakarta

Asshiddiqie, Jimly, 2006, Pengantar Ilmu Hukum Tata Negara, Sekretariat Jenderal dan Kepaniteraan Mahkamah Konstitusi, Jakarta

Bonari, 2004, Pengantar Hukum Pajak, RajaGrafindo Persada, Jakarta
HR, Ridwan, 2006, Hukum Administrasi Negara, PT RajaGrafindo Persada, Jakarta, Huda, Ni'matul 2005, Hukum Tata Negara Indonesia, PT RajaGrafindo Persada, Jakarta Marzuki, Peter Mahmud, 2005, Penelitian Hukum, Fajar Interpratama Offset, Jakarta

Sutedi, Adrian, 2008, Hukum Pajak dan Retribusi Daerah, Ghalia Indonesia, Jakarta

Saidi, Djafar, 2011, Pembaruan Hukum Pajak, PT RajaGrafindo Persada, Jakarta

\section{Peraturan Perundang-Undangan}

Undang-Undang Dasar Negara Republik Indonesia Tahun 1945.

Undang-Undang Nomor 28 Tahun 2009 tentang Pajak dan Retribusi Daerah.

Undang-Undang Nomor 23 Tahun 2014 Tentang Pemerintahan Daerah.

Peraturan Daerah Provinsi Bali Nomor 1 Tahun 2011 Tentang Pajak Daerah.

Standar Operasional Prosedur (SOP) Pengenaan Pajak Progresif Untuk Kendaraan Bermotor Pada Dinas Pendapatan Provinsi Bali Nomor : 973/4494/Pajak/ Dispenda 


\section{Majalah}

Income, 2014, Majalah Triwulan

Dinas Pendapatan Provinsi Bali, Pajak

Progresif Wujudkan Rasa Adil

\section{Internet}

Tinjauan Hukum Pajak Kendaraan bermotor dan Bea Balik Nama KEndaraan Bermotor Dalam Rangka Peningkatan Pendapatan Asli Daerah", Tersedia di http://jdih.bpk.go.id/ wp-conten/uploads/2013/05/ T u lis a n - H u ku mi Pajak Kendaraanikoreksi-Bu-Herny. pdf, diakses tanggal 10 Juli 2016. 